\title{
SYNTHESIS AND FORMING BEHAVIOUR OF AA7075-TiC POWDER-METALLURGY COMPOSITES
}

\author{
SINTEZA IN FORMIRANJE AA7075-TiC P/M KOMPOZITOV
}

\author{
Saravanan Chinnaiyan', Subramanian Karuppazhagi², Anandakrishnan Veeramani ${ }^{3}$, \\ Sathish Shanmugam ${ }^{3}$ \\ ${ }^{1}$ Department of Mechanical Engineering, University College of Engineering, Bharathidasan Institute of Technology Campus, Anna University, \\ Tiruchirappalli-620024, Tamil Nadu, India \\ 2Department of Mechanical Engineering, Government College of Engineering, Srirangam-620012, Tamil Nadu, India \\ ${ }^{3}$ Department of Production Engineering, National Institute of Technology, Tiruchirappalli-620015, Tamil Nadu, India \\ csaravananauto5@gmail.com
}

Prejem rokopisa - received: 2017-11-15; sprejem za objavo - accepted for publication: 2018-08-02

doi:10.17222/mit.2017.189

\begin{abstract}
Aluminium 7075 is frequently used in aircraft structures. Aluminium metal-matrix composites with $0 \% \mathrm{TiC}(w / \%), 8 \% \mathrm{TiC}$ and $16 \% \mathrm{TiC}$ were produced using the powder-metallurgy technique. Metallurgical studies, such as X-ray diffraction (XRD) and scanning electron microscopy (SEM), were made to confirm the occurrence of reinforcements. A cold-upset test was conducted on the synthesized composites and different stress parameters were calculated to study the forming behaviour of the produced composite in the tri-axial stress-state condition. The values of the stresses were found to be highest for the aluminium composite reinforced with AA7075 + $16 \%$ TiC.

Keywords: AA7075, metal-matrix composite, cold upsetting, formability
\end{abstract}

Najbolj pogosto uporabljana aluminijeva zlitina za letalske strukture je Al zlitina 7075. Avtorji v tem članku opisujejo izdelavo kompozita z Al matrico z $0 \% \mathrm{TiC}(w / \%), 8 \% \mathrm{TiC}$ in $16 \% \mathrm{TiC}$ s postopkom metalurgije prahov. Izvedli so metalurške preiskave, kot sta rentgenska difrakcija (XRD) in vrstična elektronska mikroskopija (SEM), da bi potrdili navzočnost ojačitvene faze. Izvedli so hladni kovaški test nakrčevanja na sintetiziranih kompozitih. Da bi lahko raziskovali obnašanje materiala med tvorbo kompozita, so izračunali različne napetostne parametre $\mathrm{v}$ pogojih triosnega napetostnega stanja. Ugotovili so, da najvišje napetosti nastajajo pri formiranju Al kompozita AA7075 s $16 \%$ TiC.

Ključne besede: AA7075, kompozit s kovinsko (Al) matrico, hladni kovaški (krčilni) preizkus, oblikovalnost

\section{INTRODUCTION}

Composite material is the term that made a paradigm shift in the field of material science. It introduces a new engineered material with improved properties for required applications. In the area of composites, metalmatrix composites have wider applications owing to their enhanced material properties. Aluminium metal-matrix composites have their own place, particularly in the field of aerospace, and the marine and automotive industries. ${ }^{1,2}$ Reinforcements of different types and forms are available; they can be selected based on the required property and the modes of fabrication. Aluminium-based composites will generally be processed through casting and the powder-metallurgy route. Powder metallurgy is a technique that is used to synthesize a material with a near net shape. ${ }^{3}$ There are six considerations when designing with powder metallurgy, i.e., material systems, size, properties, complexity, quantity, cost and tolerances. There are two broader classifications in the processing technique: one is the conventional pressingsintering process and the other is the full-density process. The most common is the conventional pressing-sintering technique. ${ }^{4}$ Several reinforcements like silicon carbide, boron carbide, alumina, titanium carbide, titanium dioxide, titanium diboride, zirconium diboride etc. are available and titanium carbide has its exceptional properties, such as low density, high hardness, high stability and good wettability. ${ }^{5}$ In order to evaluate the potential of failure for any material, it is necessary to conduct a workability study along with its failure criterion. ${ }^{6}$ Many research works were carried out with metal-matrix composites, and some of them are discussed. Hassani et al. synthesized a porous aluminium composite reinforced with silicon carbide particles using the powder-metallurgy technique and studied the influence of milling time on the metallurgical and mechanical properties of the composite. ${ }^{7}$ Jeyasimman et al. synthesized an aluminium nano-composite reinforced by multi-walled carbon nanotubes and studied the metallurgical and workability behaviour of the produced composite. ${ }^{8}$ Lee et al. studied the influence of a homogenization treatment on the mechanical properties and the workability of the $\mathrm{AlMg}_{5} \mathrm{Si}_{2} \mathrm{Mn}$ alloy. ${ }^{9}$ Liu et al. made a hot-compression test at different temperatures and strain rates and obtained the optimum condition through a processing map. ${ }^{10}$ Narayan et al. produced aluminium composites reinforced with $4 \%$ of TiC, WC, $\mathrm{Fe}_{3} \mathrm{C}$ and $\mathrm{Mo}_{2} \mathrm{C}$ through powder metallurgy and found a higher densification for the TiC-reinforced composite. ${ }^{11}$ 
Anandakrishnan et al. synthesized in-situ AA7075-TiC composites using the stir-casting technique and studied the formability behaviour of the composite. ${ }^{5}$ Devi et al. synthesized in-situ AA $7075 / \mathrm{Al}_{2} \mathrm{O}_{3}$ composites through the powder-metallurgy technique and studied its corrosion behavior. ${ }^{12}$ Narayanasamy et al. synthesized in-situ $\mathrm{Cu}-\mathrm{TiC}$ composites through the powder-metallurgy technique and studied the effect of copper addition and the aspect ratio on the formability behavior. ${ }^{13}$ Ravichandran et al. synthesized an aluminium metal-matrix composite with titanium dioxide as the reinforcement using the powder-metallurgy technique and studied its workability behavior. ${ }^{14}$ Govindan and Gowthanithankachi synthesized aluminium composites with $\mathrm{ZrO}_{2}$ to investigate their tensile behaviour and found an improved strength for $12 \%$ of $\mathrm{ZrO}_{2}{ }^{15}$ Ravichandran et al. produced hybrid aluminium metal-matrix composites reinforced with titanium dioxide and graphite through the powder-metallurgy technique and studied the effect of titanium dioxide and graphite additions on the densification and deformation behavior. ${ }^{3}$ Narayanasamy et al. manufactured an aluminium metal-matrix composite with alumina as the reinforcement using the powder-metallurgy technique and studied the mechanisms involved in the geometric and matrix work hardening. ${ }^{16}$ Bensam raj et al. manufactured an aluminium metal-matrix composite with silicon carbide as the reinforcement using the powder-metallurgy technique and studied the effect of the sintering temperature on the workability behaviour of the produced composite. ${ }^{17}$ Moazami-Goudarzi et al. manufactured an aluminium metal-matrix composite with nano silicon carbide as the reinforcement using the powder-metallurgy technique and found the addition of nano SiC improved the hardness and the densification of the composite. ${ }^{18}$ Ravindran et al. studied the metallurgical, mechanical and tribological behaviours of a hybrid aluminium composite with silicon carbide and graphite as the reinforcement. ${ }^{19}$ Ma et al. fabricated a $\mathrm{Ni}-30 \% \mathrm{SiC}(x / \%)$ composite using the powder-metallurgy technique and found that the properties of the coated $\mathrm{SiC}$ particles are improved effectively. ${ }^{20}$ Ilayaraja et al. manufactured a copper-matrix composite with $\mathrm{TiO}_{2}$ and graphite as the reinforcement using the powder-metallurgy technique to investigate the formability behaviour and found the addition of the reinforcement improved the true stresses. ${ }^{21}$ Elango et al. manufactured a hybrid aluminium-matrix composite with $\mathrm{TiO}_{2}$ and silicon carbide to investigate its tribological behaviour and observed an increased hardness with increased reinforcement additions. ${ }^{22}$ With reference to the earlier studies, an attempt was made to synthesize an aluminium metal-matrix composite AA7075 with TiC as the reinforcement for different weight percentages, i.e., $0 \%, 8 \%$ and $16 \%$, using the powder-metallurgy technique and to study the formability behaviour of that composite.

\section{EXPERIMENTAL PART}

Aluminium 7075 powder was taken as the matrix material and $\mathrm{TiC}$ was taken as the reinforcement. The powders were weighed in a precise weighing machine to obtain the required proportions of AA7075, AA7075 + $8 \% \mathrm{TiC}(w / \%)$ and AA7075 $+16 \% \mathrm{TiC}$. The weighed powders were blended in a ball mill to achieve the homogenous powder mixtures. Then the powders were compacted in a hydraulic machine to realize the green compacts, after which they were sintered in a furnace at a temperature of $600{ }^{\circ} \mathrm{C}$ and allowed to cool to room temperature. ${ }^{4}$ From the sintered composite, samples for the cold upsetting and metallographic analyses, such as $\mathrm{X}$-ray diffraction and scanning electron microscopy, were made and the analyses was made in a Rigaku Ultima and a Vega 3 Tescan, respectively. The initial dimensions of the cold upset samples, i.e., top diameter, bottom diameter, bulge diameter and height, were measured and recorded. Then the samples were subjected to a compressive incremental load of $2 \mathrm{t}$, between the mirror-polished flat dies, in the hydraulic machine until the vicinity of the crack at the periphery of the sample surface. Then the dimensions of the samples were measured and recorded at each and every incremental load. Based on the theoretical relationships, as stated in Equations (1-5), different upsetting parameters were calculated under the tri-axial stress-state condition. ${ }^{3}$

$$
\begin{aligned}
& \text { Axial stress, } \quad \sigma_{z}=\frac{\text { Applied Load }}{\text { Contact Area }} \\
& \text { Axial true strain, } \varepsilon_{z}=\ln \left(\frac{h_{0}}{h_{\mathrm{f}}}\right) \\
& \text { Hoop stress, } \\
& \text { Hydrostatic stress, } \sigma_{0}=\left(\frac{(1+2 \propto)}{(2+\propto)}\right) \sigma_{z} \\
& \text { Effective stress, } \sigma_{\mathrm{eff}}=\sqrt{\left(\frac{\sigma_{z}+2 \sigma_{\theta}}{3}\right)}
\end{aligned}
$$

\section{RESULTS AND DISCUSSION \\ 3.1 X-ray diffraction (XRD) analysis}

The X-ray diffraction analysis of the composite AA7075 $+8 \% \mathrm{TiC}$ is shown in Figure 1. From the analysis the peaks corresponding to the aluminium matrix material and the reinforcement titanium carbide are identified. It also shows successful fabrication of composite using the powder-metallurgy technique.

\subsection{Scanning electron microscopy analysis}

Figure 2 shows a scanning electron microscopy image of AA7075 + $8 \%$ TiC. It clearly reveals the presence of the reinforcement titanium carbide and their distributions are found to be homogenous over the matrix 


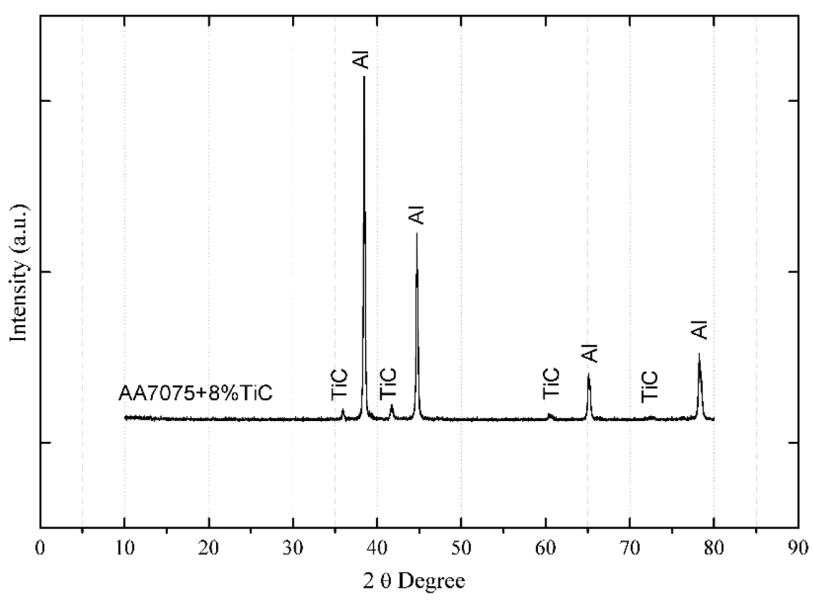

Figure 1: X-ray diffraction analysis of AA7075 + $8 \% \mathrm{TiC}$

material. In addition, the presence of TiC particles in the form of hexagonal shapes is confirmed in the microscopic analysis.

\subsection{Forming behaviour}

Figure 3 shows the true axial stresses vs. true axial strain of the aluminium composite AA7075, AA7075 + $8 \% \mathrm{TiC}$ and $\mathrm{AA} 7075+16 \% \mathrm{TiC}$ for a 0.75 aspect ratio. Figure 3a clearly revealed that the true axial stress is increased with respect to the increase in the true axial strain. It also showed that the true axial stress at any given axial strain is found to be higher for the $16 \%$ of $\mathrm{TiC}$ and lower for the $0 \%$ of $\mathrm{TiC}$, whereas the true axial stress for the $8 \%$ of $\mathrm{TiC}$ falls within the $0 \%$ of $\mathrm{TiC}$ and $16 \%$ of TiC. With the true axial stress strain graph and the Ludwik equation, ${ }^{3}$ as stated in Equation (6), the values of the strength coefficient and the strain-hardening index are attained, as shown in Table 1. The maxi-

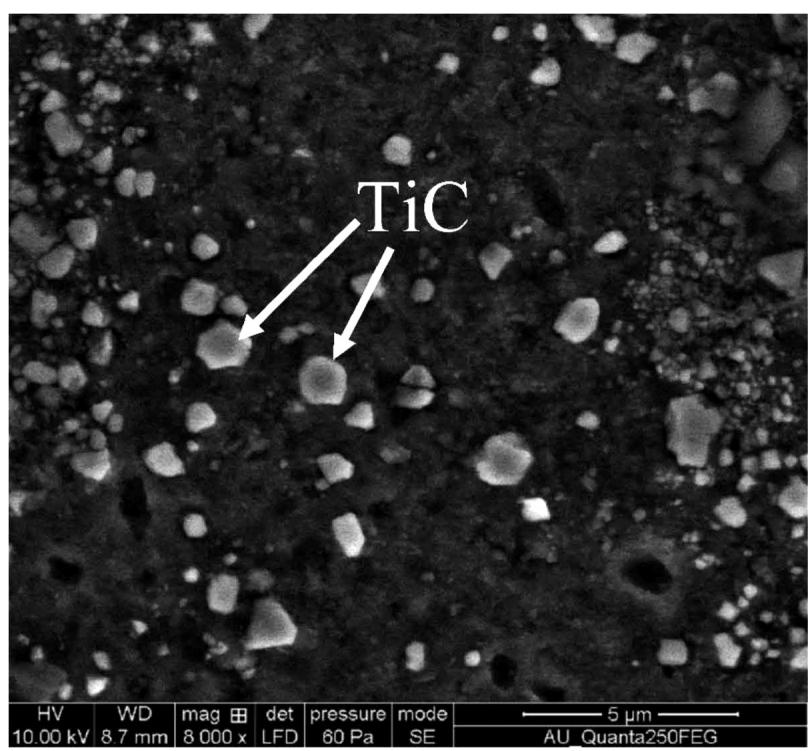

Figure 2: Scanning electron microscopy image of AA7075 + $8 \%$ TiC mum value of the strength coefficient and the strainhardening index were found to be $0.1283 \mathrm{MPa}$ and $250.61 \mathrm{MPa}$ for the higher reinforcement of $16 \% \mathrm{TiC}$. The table also shows the value of the strength coefficient increased with the addition of $\mathrm{TiC}$, whereas the strain-hardening index decreased with the addition of TiC. It clearly shows that the addition of $\mathrm{TiC}$ improves the strength of the material. The strain-hardening index is found to be less for the higher percentage of reinforcement, which means the material is highly suitable for the further processing of materials, such as cold working and forming. The composite failure was identified through the visibility of cracks on the sample peripheries, due to the shear band formation during the cold upset tests, which is very much governed by the friction factor in between the sample and the die.

Table 1: Strain-hardening index and strength coefficient of the materials

\begin{tabular}{|c|c|c|}
\hline Material & $\begin{array}{c}\text { Strain hardening } \\
\text { index }\end{array}$ & $\begin{array}{c}\text { Strength coefficient, } \\
\text { MPa }\end{array}$ \\
\hline AA7075 & 0.2675 & 185.86 \\
\hline AA7075 $+8 \% \mathrm{TiC}$ & 0.2119 & 236.76 \\
\hline AA7075 $+16 \% \mathrm{TiC}$ & 0.1283 & 250.61 \\
\hline
\end{tabular}
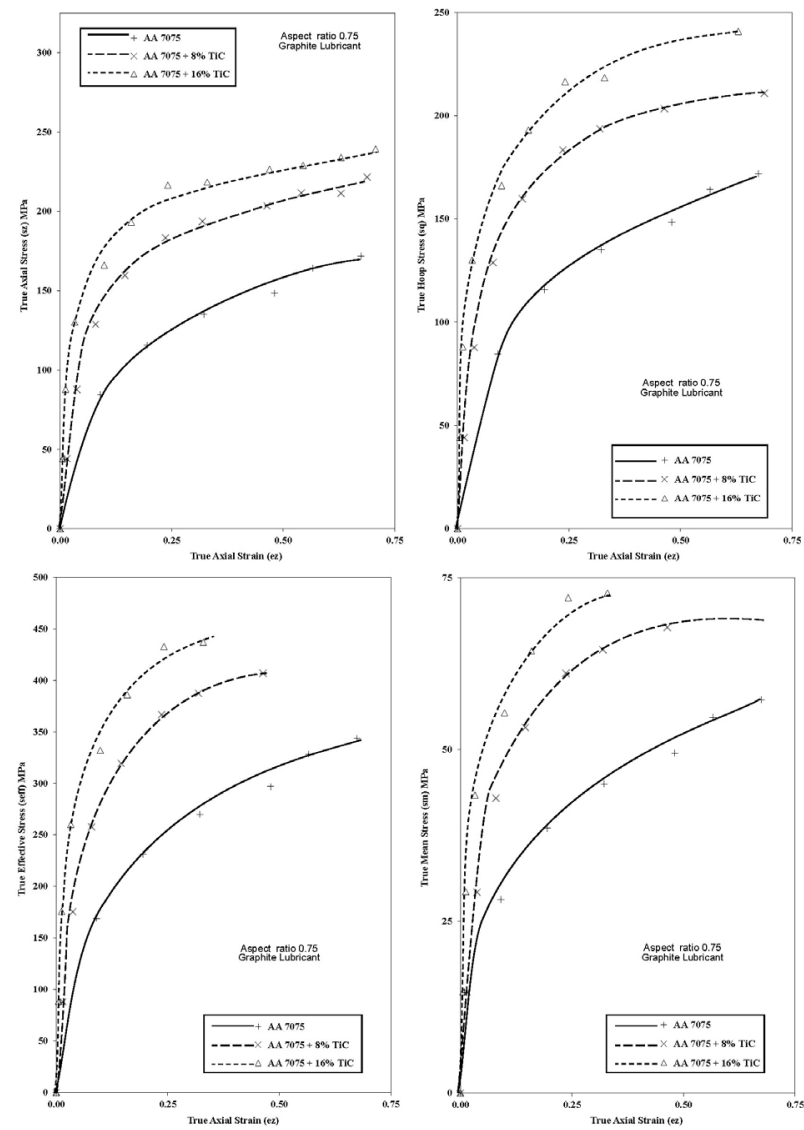

Figure 3: True axial stresses vs. true axial strain a) Axial stress, b) Hoop stress, c) Effective stress, d) Mean stress 
Figure 3b shows a graph of the true hoop stress vs. the true axial strain and it shows that the true hoop stress is increased with an increase in the true axial strain. It also showed that the true hoop stress at any given axial strain is found to be higher for the $16 \%$ of $\mathrm{TiC}$ and lower for the $0 \%$ of $\mathrm{TiC}$, whereas the hoop axial stress for the $8 \%$ of TiC falls within the $0 \%$ of $\mathrm{TiC}$ and $16 \%$ of TiC. Figure $\mathbf{3 c}$ and $\mathbf{3 d}$ shows the true effective stress and true mean stress with respect to the true axial strain. Similar to the axial stress and the hoop stress, the effective stress and the mean stress are increased with an increase in the true axial strain and also the higher values of stresses are attained at $16 \%$ of $\mathrm{TiC}$, whereas the lower stresses are attained at $0 \%$ of TiC. From the deformation results, it was observed that the increased percentage of TiC enhances the load-bearing capacity of the composite, which leads to a higher densification and deformation of the composite with $16 \%$ of TiC.

\section{CONCLUSIONS}

Aluminium metal-matrix composites of AA7075, $\mathrm{AA} 7075+8 \% \mathrm{TiC}$ and $\mathrm{AA} 7075+16 \% \mathrm{TiC}$ were manufactured by the powder-metallurgy route. The presence of the reinforcements was confirmed by x-ray diffraction and scanning electron microscopy. From the cold upsetting, it was observed that the addition of TiC improved the value of stresses, i.e., the true axial stress, true hoop stress, true effective stress and true mean stress for a given axial strain. The highest values of the stresses are obtained for the composite AA7075 + $16 \% \mathrm{TiC}$ in all stresses with the true axial strain.

\section{REFERENCES}

${ }^{1}$ A. Nagaraj, S. Palanisamy, Effect of particles size on the mechanical properties of SiC-reinforced aluminium 8011composites, Mater. Tehnol., 51 (2017) 4, 667, doi:10.17222/mit.2016.252

${ }^{2}$ C. Saravanan, K. Subramanian, V. A. Krishnan, R. S. Narayanan, Effect of Particulate Reinforced Aluminium Metal Matrix Composite - A Review, Mech. Mech. Eng., 19 (2015) 1, 23

${ }^{3}$ M. Ravichandran, A. N. Sait, V. Anandakrishnan, Al-TiO $2-\mathrm{Gr}$ powder metallurgy hybrid composites with cold upset forging, Rare Met., 33 (2014) 6, 686, doi:10.1007/s12598-014-0239-x

${ }^{4}$ C. M. Lewandowski, N. Co-investigator, C. M. Lewandowski, Powder Metal Technologies and Applications, ASM International: Materials Park, OH, 7 (2015), 2762, doi:10.1017/ CBO9781107415324.004

${ }^{5}$ V. Anandakrishnan, S. Baskaran, S. Sathish, Synthesis and Forming Behavior of In-Situ AA 7075 - TiC Composites, Adv. Mater. Res., 651 (2013), 251, doi:10.4028/www.scientific.net/ AMR.651.251

${ }^{6}$ ASM International, Handbook of workability and process design, 2003

A. Hassani, E. Bagherpour, F. Qods, Influence of pores on workability of porous $\mathrm{Al} / \mathrm{SiC}$ composites fabricated through powder metallurgy + mechanical alloying, J. Alloys Compd., 591 (2014), 132, doi:10.1016/j.jallcom.2013.12.205.
${ }^{8}$ D. Jeyasimman, R. Narayanasamy, Effect of coarse grain content on microstructure, cold workability and strain hardening behavior of trimodaled AA 6061 nanocomposites reinforced with multi-walled carbon nanotubes, Advanced Powder Technol., 27 (2016) 4, 1845, doi:10.1016/j.apt.2016.06.018.

${ }^{9}$ Y.-S. Lee, J.-H. Cha, S.-H. Kim, C.-Y. Lim, H.-W. Kim, Effect of pre-homogenization deformation treatment on the workability and mechanical properties of $\mathrm{AlMg}_{5} \mathrm{Si}_{2} \mathrm{Mn}$ alloy, Mater. Sci. Eng. A, 685 (2017), 244, doi:10.1016/j.msea.2016.12.107

${ }^{10}$ Y. Liu, C. Geng, Q. Lin, Y. Xiao, J. Xu, W. Kang, Study on hot deformation behavior and intrinsic workability of 6063 aluminum alloys using 3D processing map, J. Alloys Compd., 713 (2017), 212, doi:10.1016/j.jallcom.2017.04.156

${ }^{11}$ S. Narayan, A. Rajeshkannan, Studies on formability of sintered aluminum composites during hot deformation using strain hardening parameters, J. Mater. Res. Technol., (2017), 1, doi:10.1016/ j.jmrt.2016.03.012

${ }^{12}$ R. Devi, C. Raja, S. Sivaprakash, V. Anandakrishnan, Synthesis of Al7075 Alloy/ $/ \mathrm{Al}_{2} \mathrm{O}_{3}$ Composite and Corrosion Study, Adv. Mater. Res., 984-985 (2014), 541-545, doi:10.4028/www.scientific.net/ AMR.984.541

${ }^{13}$ R. Narayanasamy, V. Anandakrishnan, K. S. Pandey, Some aspects on plastic deformation of copper and copper-titanium carbide powder metallurgy composite preforms during cold upsetting, International Int. J. Mater. Form., 1 (2008) 4, 189, doi:10.1007/s12289-0080383-7

${ }^{14}$ M. Ravichandran, A. N. Sait, V. Anandakrishnan, Effect of $\mathrm{TiO}_{2}$ in aluminum matrix on workability behavior of powder metallurgy composites during cold upsetting, Int. J. Mater. Res., 105 (2014) 4, 358. doi:10.3139/146.111034

${ }^{15}$ K. Govindan, R. J. Gowthanithankachi, Tensile behaviour and fractography analyses of $\mathrm{LM} 6 / \mathrm{ZrO}_{2}$ composites, Mater. Tehnol., 51 (2017) 3, 549, doi:10.17222/mit.2015.319

${ }^{16}$ R. Narayanasamy, V. Anandakrishnan, K. S. Pandey, Effect of geometric work-hardening and matrix work-hardening on new constitutive relationship for aluminium-alumina P/M composite during cold upsetting, Int. J. Mech. Mater. Des., 4 (2008) 3, 301, doi:10.1007/s10999-008-9072-4.

${ }^{17}$ J. Bensam Raj, P. Marimuthu, M. Prabhakar, V. Anandakrishnan, Effect of sintering temperature and time intervals on workability behaviour of Al-SiC matrix P/M composite, Int. J. Adv. Manuf. Technol., 61 (2012) 1-4, 237, doi:10.1007/s00170-011-3709-4

${ }^{18}$ M. Moazami-Goudarzi, F. Akhlaghi, Effect of nanosized SiC particles addition to $\mathrm{CP} \mathrm{Al}$ and $\mathrm{Al}-\mathrm{Mg}$ powders on their compaction behavior, Powder Technol., 245 (2013), 126, doi:10.1016/ j.powtec.2013.04.025

${ }^{19}$ P. Ravindran, K. Manisekar, S. Vinoth Kumar, P. Rathika, Investigation of microstructure and mechanical properties of aluminum hybrid nano-composites with the additions of solid lubricant, Mater. Des., 51 (2013), 448, doi:10.1016/j.matdes. 2013.04.015

${ }^{20}$ H. Ma, Y. Lu, H. Lu, X. Meng, Fabrication of Ni/SiC composite powder by mechanical alloying and its effects on properties of copper matrix composites, Int. J. Mater. Res., 108 (2017) 3, 213, doi:10.3139/146.111475

${ }^{21}$ K. Ilayaraja, P. Ranjith Kumar, V. Anandakrishnan, S. Sathish, M. Ravichandran, R. Ravikumar, Synthesis, characterization and forming behavior of hybrid copper matrix composites produced using powder metallurgy, Int. J. Mater. Res., 180 (2017), 7, 586, doi:10.3139/146.111510

${ }^{22}$ G. Elango, B. K. Raghunath, K. Palanikumar, Experimental analysis of the wear behavior of hybrid metal-matrix composites of $1 \mathrm{~m} 25 \mathrm{al}$ with equal volumes of $\mathrm{SiC}+\mathrm{TiO}_{2}$, Mater. Tehnol., 48 (2014) 6, 803 